\title{
SOME ASPECTS OF DEVELOPMENT IN RADAR TECHNOLOGY IN THE CONTEXT OF A CCURATE POSITIONING
}

\begin{abstract}
In the end of XX century we were witnesses of the revolution in a radio-navigation, which led to the present domination of GPS. Dozens of radio-navigation systems disappeared. However now in many papers more and more often we can read an opinion, that GNSS monopoly becomes dangerous. This results from the similar sensibility of all GNSS systems on the same disturbances consequential from the similar radiofrequency band and similarly low powers of the signal. There is a growing approval in the maritime world that GNSS will not provide a required resilience because of common vulnerabilities.

An anticipated radio navigation system should be a combination of systems, providing redundancy and effective work when GNSS does not work properly. Lately a lot of authors commonly pointed-out a potential advantages of modified Loran (e-Loran), however surely still it will be only a potential option, particularly for the southern hemisphere, where this system has never existed. An issue of alternative systems becomes urgent, because of the growing concern about GNSS system operation. The solution should not demand high financial effort, well fit to the existing law and utilize a present technology. The paper presents a general outlook of potential development in a present radar devices considering their use as an element of a positioning system. In this context radar seems to be an attractive option, however its utilization as an alternative for GNSS should reach considerably higher technical performances. The accessible information prove that it is possible to reach a higher accuracy of the position obtained from the modified radar in the future, especially with the suitable navigational infrastructure on shore.
\end{abstract}

\section{Keywords:}

resilient positioning and time system, solid state radar, positioning, accuracy. 


\section{INTRODUCTION}

Accurate navigation is one of the most important factors determining safety at sea. GNSS technology, which is in use all over the world in different variants by wide spectrum of users on the seas and ground, in the air and in the space, dominates in this field. Although satellite navigation systems are the primary method of nowadays navigation, all GNSS are vulnerable to intentional and accidental interference and jamming. This is caused by the extremely low signal strength and the same radiofrequency band. New question in this context is possible spoofing or meaconing, which at the moment seems be less threat, but it can undergo change. A reliance on only a single source of a position with considerable risk of disturbances is not acceptable in any kind of navigation. Therefore the provision of backup Positioning, Navigation and Timing (PNT) service is essential [Report, 2008]. At the moment modernized Loran is suggested as a back-up positioning system on some areas of the world. Vision-based navigation systems are discussed as well recently [Thompson and Pick, 1994; Naus and Wąż, 2014].

However issue of global coverage and accuracy is still discussed and in some opinion radar can play the similar role, however equipment, that is already provided, need improvements. From this point of view it is important, that potential users are familiar with this technique. GLA Radio Navigation Plan can an example of this tendencies. In this document [GLA, 2007] four directions of technical development strategy are pointed:

- the introduction of Galileo and modernized GPS service;

- the deployment of AIS as an AtoN;

- the prospect of the European-wide provision of eLoran;

- new technology radar that may not trigger existing racons.

According to this source the new radio navigation service, among other things, will be characterized by the new technology S-band racons. However radar used at present does not assure comparable accuracy with GPS. The standard navigation radar accuracy is $1 \%$ of range and is partially determined by echo shape but mainly by rather low bearing accuracy. This depend on the antenna beam angle and accuracy of ship's heading which is the reference for bearing measurements. It strongly depends on the distance to the object and in fact we should assume, that it is greater than 1 degree. At the moment accuracy of distance determination by radar is better, around $30 \mathrm{~m}$ or less, but it is still worse than by satellite technology [BOLE et al., 2014]. So there is a number of problems to resolve. 
These problems are less essential when we use radar to the collision avoidance, mainly because the exact measurement of distance is not the aim as first of all we endeavour to maintenance proper distance to the other ship. But when we are talking about radar positioning, the traditional approach is insufficient. The biggest part of the fixed position accuracy is affected by the reference object's position. So we need to ensure that objects, which give signal reflection are recognized properly. It should be assumed that many land and sea objects reflects a signal (Fig. 1). A part of this problem consist in geometrical proprieties of the screen and quality of radar picture.
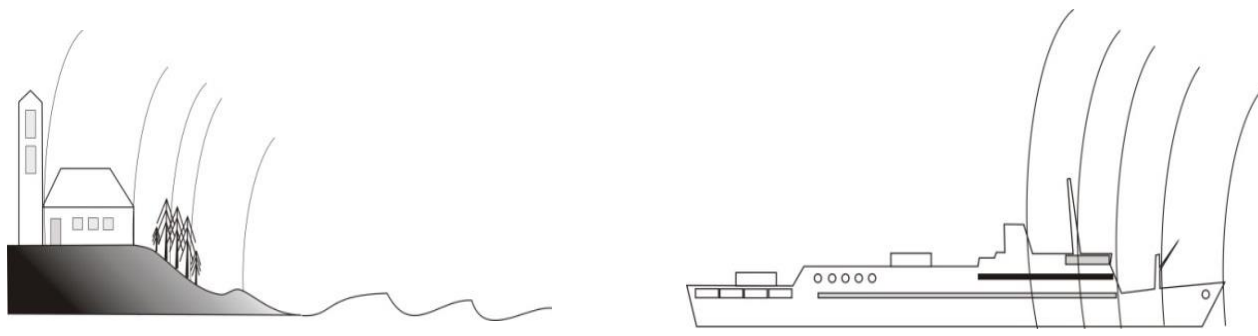

Fig. 1. Idea of radar energy reflection

The system with computational possibilities would be also desirable, so user can get positioning information (latitude and longitude) in digital form: like on GPS receiver. Nowadays radar picture interpretation needs specific knowledge and great experience of well-trained operator, but even then the recognition of the object on shore may be impossible. Indeed in many places racons (radar beacons) are established, so identity of land object and determination of bearing and distance is easier, however we still discussing the accuracy of position about ten times worse than GPS. It is interesting, that methods of comparing radar picture with digital terrain model are discussed as the alternative positioning options for more than 30 years, but they are still on the experimental stage [Wąż, 2010].

\section{NEW CONCEPT OF RADAR POSITIONING}

A measurement method (a time difference between sending a signal and receiving the returned impulse) cannot be recognized as modern. It is proper to notice that similar rules of time measurement are utilized in satellite systems, but 
we assure many times higher accuracies. The secret stays in modulating of the transmitted signal with the code and correlating received signal with the source. The crucial question is: can we modulate radar signal like in GNSS? It is unreasonable in case of a signal reflection from random object on the shore but it can be done when some active source of such signals will be distributed on shore. Radiofrequency applied in radar technology $(3-10 \mathrm{GHz})$ is not so far to GPS one $(1.5 \mathrm{GHz})$, especially $\mathrm{S}$-band. If we can modulate this signal in similar manner as we do it in GPS technology we can measure distances with accuracy of a few meters. Phase Shifting is preferred in satellites technology at the moment while in radar bands Frequency Modulation is favoured (coherent radar, continuous wave radar), however other concepts are also discussed [Bole et al., 2014].

A condition of such GNSS-like radar system set-up is the precise work of racons' clocks as well as ships radar clock. It is possible, because we have at our disposal the perfect scale of the time, which is GPS one. In addition we can conserve the time-scale in the sufficient degree using AIS. Idea of new positioning method depends on possibility of measuring an exact distance from enhanced radar to enhanced racon and calculate position using the information about racon position [The potential use, 2012]. Both need some manipulation with radar signal, which is accessible now with nowadays electronics.
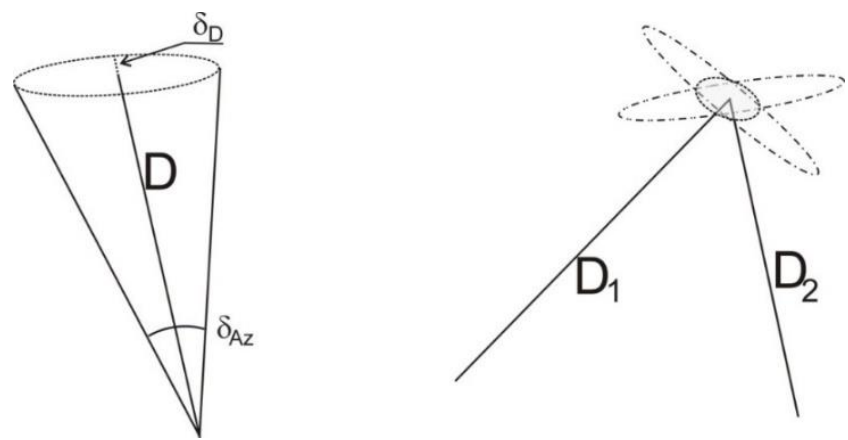

Fig. 2. Differences between accuracy of position determined from azimuth-distance method and two distances: $D-$ distance, $\delta_{A z}$ - error of azimuth, $\delta_{D}$ - error of distance

If so, the question of the size of coverage zones of such a service appears. Coverage of one racon has circle shape and it applicatory size depends on ratio of sea/land in this area. The common part of two circles is an only small part of them (Fig. 3). So this is not effective solution, but in some configuration it can be more useful, especially in estuaries, harbour approaches etc. When two e-racons 
are available and the positioning accuracy does not depend on the distances from them it can be comparable to pure GPS (without augmentation). This is not a solution for open sea navigation, but in restricted waters and particularly sensitive areas, like approaches to harbours, can play the role of a back-up system.

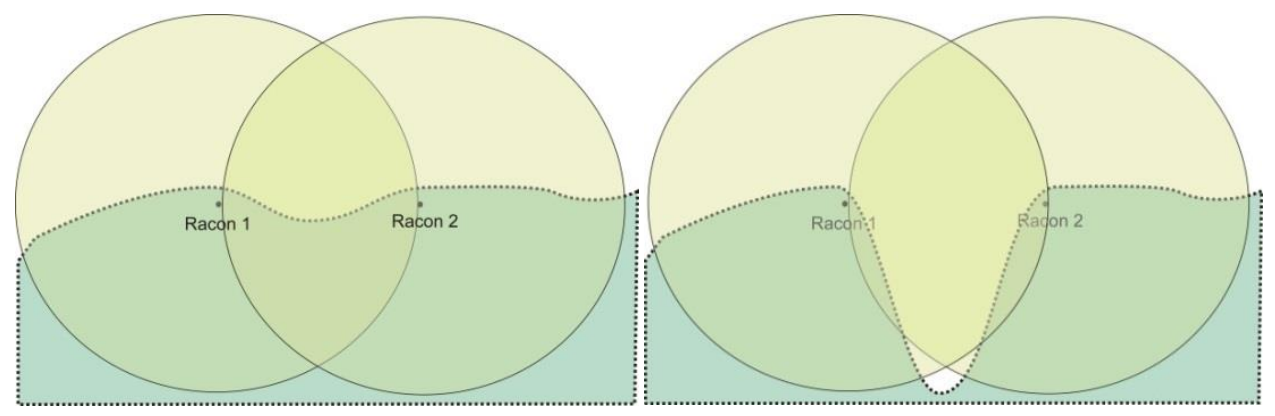

Fig. 3. Coverage of two distance positioning systems for two different configurations of a coast-line

\section{EQUIPMENT SPECIFICATIONS}

Proposed solution needs additional elements in radar as well as in racon for transmitted signal modulation and it's demodulation on the user side. Various solutions can be discussed in this context. First of all, a radar impulse can trigger e-racon to send answer-signals containing additional information about racon ID and its position (Fig. 4). In this case additional, independent receiver on the ship can receive signal, demodulate it and calculate a position. Crucial question is a method of time measurement. One option is, that radar signal can start time measurement till the racon signal is received, however in fact it is still an old impulse technology. An independent time-keeping device on the racon and additional time-stamp transmitted in mentioned before racon signal seems to be a better solution. In fact, information about racon position can be omitted if it will be accessible in any database, but racon signal should be identified by its ID and should deliver information about the travel time of a signal. It can be executed if a signal transmitted by racon will consist time-code similar to GPS one.

Experiment similar to this foundations was conducted by GLA and Furuno on the North Sea east of England, near Lowestoft and Southwold lighthouses with a prototype of X band Solid State Shipborne radar in 2014 [Ward et al., 2014]. 
These lighthouses are situated about $10 \mathrm{Nm}$ apart on a relatively low-lying coastline and trials were carried out at distances up to $10 \mathrm{Nm}$ off the coast. The experimental radar was installed on-board Trinity House Vessel 'Alert' and position was calculated on the basis of two distances in combination with latitude and longitude of both lighthouses coded using FSK modulation on the dash of the Morse D character of the racons.
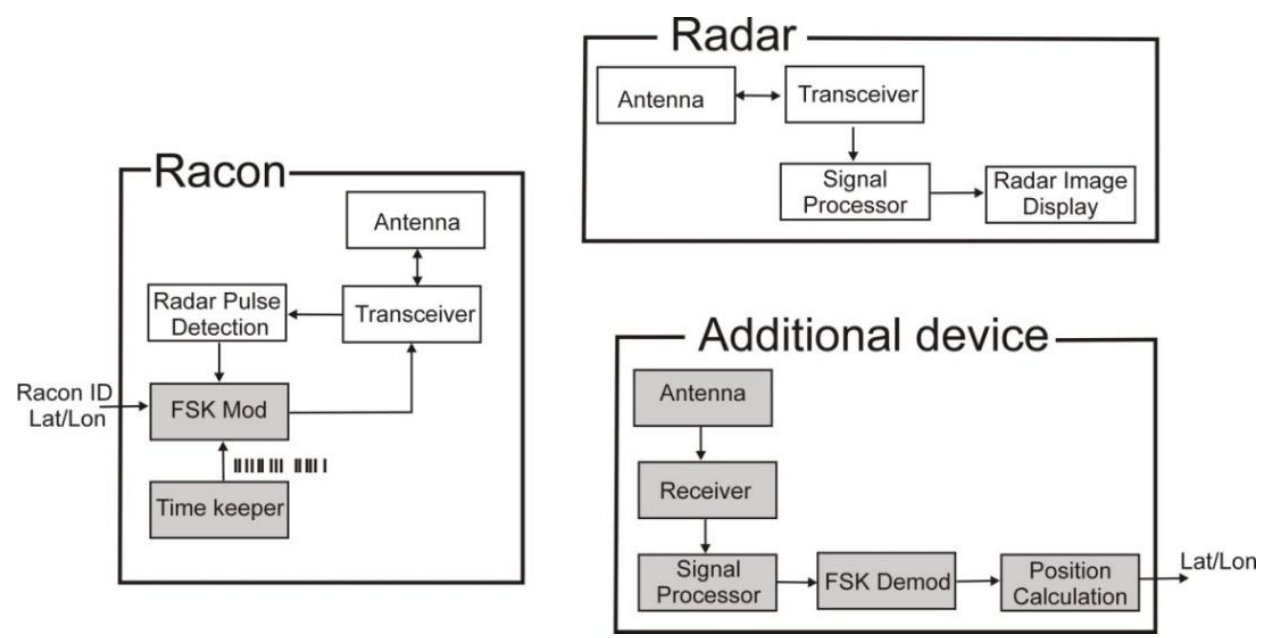

Fig. 4. Possible system configuration, shadow background indicates additional components

The locations of racons and equipment on the ship were not optimal, what would have influence on results, however general conclusions concerning such idea can be deduced. During the trials a usable range of $10 \mathrm{Nm}$ was proved, but the maximum ranges at which the racons could be seen was about $20 \mathrm{Nm}$ in spite of the small height of racon transmitters above the sea level. Position accuracies also varied considerably, mainly depending on geometry of the system, but position combined from two distances has an accuracy of about 5-10 m.

\section{CONCLUSIONS}

There is a growing approval in the maritime industry that GPS alone cannot provide robust positioning and multiple GNSS will not provide the resilience required, because of common vulnerabilities. So marine community needs 
some alternatives to GNSS, which could be terrestrial radionavigation system such as e-Loran, but it is promising to find out other alternatives, for example short range racon-radar system. This is important because of a questionable e-Loran accuracy and a need of a precise harbor approach system.

Radar positioning is technically feasible. Mentioned trials [Ward et al., 2014] have shown that the required performance can be achieved with radar positioning, within certain range limitations. It could be a backup option within accuracy about $10 \mathrm{~m}$ off the coast. Important feature of this option is that modified racons would require no regulatory changes, other than agreement on standards, possible through ITU and IALA. Indeed the cost could be substantial, but it will be much lower than a cost of Loran maintenance. This is an essential question in the face of the entire lack of the Loran infrastructure on the south hemisphere. On the other hand modified radar infrastructure can be a back-up positioning system only on some restricted waters, it cannot play this role at the open sea.

Presented option demands introduction of new technological solutions, in fact new class of racons and new kind of ship's receiving devices, but no changes in ship's radar technology is needed. The present magnetron radar can still be in use. Another question is a period of time to implement of such an option, if that option will be chosen.

\section{REFERENCES}

[1] Bole A., Wall A., Norris A., Radar and ARPA Manual, Elsevier, 2014.

[2] GLA Radio Navigation Plan, 2007.

[3] The Potential Use of Advanced Marine Radar for the Absolute Positioning of Vessels in Coastal Waters, R \& RNAV Report No: RPT-17-NW-12, GLA, 2012.

[4] Report of the Maritime Safety Committee, 85th Session, MSC 85/26/Annex 20, IMO, 2008.

[5] Enhanced Radar Positioning, e-NAV 10/8/3, IALA, 2011.

[6] Naus K., Wąż M., Determining ship position in a harbour based on omnidirectional image of the coastline, 'Annual of Navigation', 2014, No. 21.

[7] Thompson W. B., Pisk H. L., Jr., Vision-Based Navigation, Proc. ARPA Image Understanding Workshop, 1993, [online], https://www.cs.utah.edu/ thompson/ publications/Thompson:1993:VBN.pdf, [access 30.05.2015].

[8] Wąż M., Problems with Precise Matching Radar Image to the Nautical Chart, 'Annual of Navigation', 2010, No. 16. 
[9] Ward N., Safar J., Grant A., Kojima T., Mueller P., Absolute Radar Positioning, Proceedings of ENC 2014 Conference, Rotterdam 2014.

Received August 2015

Reviewed November 2015

\author{
ANDRZEJ FELSKI \\ Polish Naval Academy \\ a.felski@amw.gdynia.pl
}

\title{
STRESZCZENIE
}

W końcu XX stulecia byliśmy świadkami rewolucji w radionawigacji, co doprowadziło do obecnej dominacji GPS. Zniknęly dziesiątki systemów radionawigacyjnych. Jednak obecnie w wielu wystąpieniach coraz częściej wyraża się opinie, że monopol GNSS staje się ryzykowny. Przyczyną tych obaw jest fakt stosowania zbliżonych rozwiązań technologicznych i wykorzystywania, w istocie tego samego pasma częstotliwości radiowych we wszystkich systemach nawigacji satelitarnej, co czyni te systemy jednakowo podatnymi na zakłócenia.

W takim razie należałoby oczekiwać, że system radionawigacyjny powinien być kombinacją systemów, które zapewnią zarówno wzajemną redundancję, jak i stabilną pracę wówczas, gdy GNSS nie pracuje właściwie. Ostatnio wielu autorów wskazuje na potencjalne korzyści zmodyfikowanej wersji systemu Loran (e-Loran), jednak należy to traktować jak jedną z opcji, szczególnie wobec faktu, że na półkuli południowej ten system nigdy nie istniał. Tymczasem coraz bardziej powszechne obawy o funkcjonowanie GNSS powodują, że kwestia alternatywnych rozwiązań staje się pilną. Poza tym byłoby pożądane, aby proponowane rozwiązania uwzględniały zarówno ograniczone nakłady finansowe, jak i w miarę możliwości obowiązujące uwarunkowania prawne oraz stan rozwoju techniki. Takim rozwiązaniem zdaje się być radar. 